\title{
The Online and Campus (OaC) model as a sustainable blended approach to teaching and learning in higher education: A response to COVID-19
}

\author{
Rebecca Petronzi ${ }^{1}$ and Dominic Petronzi ${ }^{2}$ \\ 1 University of Derby, United Kingdom (ORCID: 0000-0001-7460-2264) \\ 2University of Derby, United Kingdom (ORCID: 0000-0002-3872-2725)
}

\begin{abstract}
The COVID-19 pandemic represents an unprecedented challenge for wider society and has impacted all facets of life, including Higher Education Institution (HEIs) provision for teaching and learning demanding an immediate digital response. The core challenge lies with the inherent choice made by students upon embarking on an undergraduate degree; that face-to-face learning was their preference. Now, HEIs must address this by utilising a range of digital solutions - that crucially, must also be embraced by those that no longer have the luxury to be risk averse or believe that digital solutions align with their existing pedagogical approaches. Higher Education Institutions should be - to an extent - well placed to deliver online provision. This paper aims to explore pertinent literature surrounding blended approaches with regards to key pedagogical and learning theories, with an overall aim of suggesting the Online and Campus $(\mathrm{OaC})$ model as a potential 'blueprint' that incorporates campus, synchronous and asynchronous learning experiences. We refer to asynchronous as flexible, self-paced learning, and synchronous as an environment in which learners are in the same place at a given time (either online or campus) and accessing the same materials. For the purposes of this paper - and the OaC model - both asynchronous and synchronous learning refers to online provision, and we make the distinction between face-to-face teaching by reference to 'Campus'.
\end{abstract}

Keywords: COVID-19; Blended learning; Online teaching; Student experience; Active learning

Article History: Submitted 27 August 2020; Revised 28 October 2020; Published online XX November 2020

\section{Introduction}

In unparalleled times, we can refer to wider literature surrounding existing digital provision typically for non-traditional learners - to understand the motivations and factors that might encourage student engagement. We refer now to Massive Open Online Courses (MOOCs) to consider factors that can also be embedded within blended learning provision. MOOCs have - in recent years - provided a new educational paradigm that is constantly evolving in an endeavor to break down geographical boundaries and time zones to provide knowledge on a global scale. These provide non-traditional students with the opportunity to continue to achieve educational goals (Voss, 2013). Glance (2013) suggests that this method of learning enables HEIs to make

Address of Corresponding Author

Rebecca Petronzi, Institute of Education, University of Derby, Kedleston Road, Derby, DE22 1GB, UK.

$\triangle$ r.petronzi@derby.ac.uk

How to cite: Petronzi, R. \& Petronzi, D. (2020). The Online and Campus $(\mathrm{OaC})$ model as a sustainable blended approach to teaching and learning in higher education: A response to COVID-19.Journal of Pedagogical Research, 4(4), 498-507. 
education more accessible, while Hayes (2015) considers that MOOCs also foster social inclusion, and thus serve a further purpose for the learner. However, it is worth considering whether experience of a face-to-face cohort can be replicated - or supplemented - by online provision. In recent work, Anthony et al. (2020) consider that a blended learning approach requires a balance of human mediated and technology mediated learning options. This - to an extent - supports the proposed $\mathrm{OaC}$ model in this paper, with campus sessions suggested as the human mediated option. Moreover, Tubagus, Muslim \& Suriani (2020) advocate an 'optimal' integration between face-to-face teaching and technology-based learning and would therefore mitigate some of the selfdirected learning issues that have been observed on MOOCs and the higher proportion of nonengagement/completion. Similarly, the OaC model can act as guidance for HEI practitioners whom will be engaging in an unknown medium - as blended learning differs to technology enhanced learning e.g. adding a digital quiz to campus sessions - and as there are a range of choices/methods surrounding blended learning, it may be challenging to determine the most effective approach (Stein \& Graham, 2020). Indeed, Ying and Yang (2017) in a study of academic perceptions of blended learning, reported concerns relating to additional expectations, and this may be the case without a supporting model - such as the OaC model. However, despite design challenges, blended learning may minimize extended periods of passiveness that can be observed in traditional classrooms (Baepler, Walker, \& Driessen, 2014), thus enhancing student engagement, self-management and outcomes (Means, Toyama, Murphy, Bakia, \& Jones, 2010) while allowing for more dedicated active sessions when on campus. A necessary caveat for the implementation of online-based learning is quality assurance and pedagogical design, which is an immediate consideration following the shift to online provision or blended approaches in response to the COVID-19 pandemic. As a blended approach can be a variety of combinations between online and campus learning, suggested models - such as the OaC model - could support HEI educators in determining effective approaches (Stein \& Graham, 2020). Post COVID-19, new remote and blended learning approaches demand increased practitioner technological pedagogical content knowledge (Koehler \& Mishra, 2009) - including technological proficiency and competency (Rasheed, Kamsin \& Abdullah, 2020) - and Ustun and Tracey (2020) suggest a simple design to support inexperienced students and teachers to navigate a blended learning approach. The proposed $\mathrm{OaC}$ model aims to fulfil these criteria by clearly outlining a logical and organised module pattern that balances online and campus teaching and learning. Recent pedagogical and meta-analytical work within a medical education context has supported the efficacy of a blended learning approach, with findings showing significantly and consistently increased content knowledge in comparison to traditional learning approaches (Vallee, Blacher, Cariou \& Sorbets, 2020). The meta-analytic findings suggest that researchers and educators must consider how to implement a blended course effectively. As quality/effectiveness is a core requirement within HEI programmes, we now consider this within a blended context.

\section{Quality within blended provision}

A key consideration for HEI's moving toward a blended approach is ensuring the systematic monitoring of teaching and learning to confirm standards are being met in the interest of the students (Tight, Mok, Huisman \& Morphew, 2009; Quality Assurance Agency, 2017). To some extent, academic autonomy must be utilized by HEIs to meet the needs of their learners (Day, Gu \& Sammons, 2016), for example, adapting course content. However, Chu and Westerheijden (2018) acknowledge that academic autonomy may be limited by the government's involvement in quality assurance, particularly when designing blended approaches in response to COVID-19. Arthur (2020) identified that student metrics, such as the National Student Survey (NSS) may limit the autonomy of HEIs as they work towards external and generic measures that may not align with the requirements of specific institutional student intakes. As HEIs move towards a blended approach, there must be transparency to ensure prospective students understand how they fit within a pedagogical plan, including their commitment to autonomous learning. Indeed, the 
principles of adult learning - or andragogy - insist that students must see why and how they are learning in order to engage with the delivery (Knowles, 1984). Moreover, student perception of their learning experiences also links to perceived quality of teaching, a sense of feeling supported and feeling overwhelmed (McVicar, Andrew \& Kemble, 2015). Therefore, the quality of blended provision can also be supported by the teaching approach of academics, as well as the quality of the course design. Furthermore, Shantakumari and Sajith (2015) considered HEI student perceptions of blended learning to also determine satisfaction and course efficacy. This was supported by understandable online content and activities, increased peer interactions and module objectives aligning with the content. This enhanced the learning experience. It was noted that blended learning should be designed with clear intentions surrounding instruction so that a course is designed to be blended, rather than simply delivered in a blended format. This again emphasises the importance of quality and considered instructional design, and our proposed OaC model can support educational practitioners in making the design process more structured and guided.

A common definition of blended approaches centres on amalgamating strengths of campus/face-to-face teaching and virtual/remote learning (McCutcheon, Lohan, Traynor, \& Martin, 2015). However, this must be systematically analysed and reviewed to ensure effectiveness of the blended approach (Tight, Mok, Huisman \& Morphew, 2009; Ustun \& Tracey, 2020). It has previously been considered that online content can support active and collaborative learning in both a campus and online setting (Graham, Allen, \& Ure, 2005). However, Jokinen and Mikkonen (2013) considered challenges of blended learning with regards to developing student motivation through appropriately focused tasks and content. The alignment and connection between the elements of blended learning must be considered comprehensively, otherwise asynchronous and self-directed sessions may be perceived as additional to the taught content (Ustun \& Tracey, 2020). Consequently, motivation and engagement with asynchronous tasks may be limited. This again links to considered course design, and the $\mathrm{OaC}$ model provides guidance to those whom may not be familiar with blended learning approaches. It could therefore be suggested that asynchronous learning tasks should support engagement with synchronous remote learning and face-to-face sessions, allowing students to engage with content at their own pace before applying this knowledge in problem-solving, active and collaborative learning (Ashcroft \& Foreman-Peck, 1994; Graham et al., 2005; Ustun \& Tracey, 2020). The content provided in campus, synchronous and asynchronous learning must align with the objectives of the programme, module and assessment to ensure effective constructive alignment (Biggs \& Tang, 2011). Indeed, Azhar, Mustapa, Ibrahim \& Yusoff (2015) consider effective blended learning as supporting, for example, collective collaborations, knowledge access and personal development. As a secondary benefit, effective blended learning is suggested to be cost-efficient for HEIs and minimises attendance-based issues. In sum - and in alignment with literature - we begin to propose the OaC model of blended learning that delivers teaching and collaboration through an online platform yet utilises the campus experience for consolidation of knowledge activities and application of knowledge. Thus, the campus experience becomes, by design, an active learning environment and thus students expect and anticipate this.

\section{Social Learning and Motivation through a Blended Approach}

Graded assessment was a clear extrinsic motivation for students during the COVID-19 pandemic, although it remains essential to consider that quality assured pedagogical design of online provision is pivotal to retention and completion (Hadi \& Rawson, 2016). A number of factors have been found to have associations with learner retention for online educational courses including: [1] the extent of previous education (Greene, Oswald, \& Pomerantz, 2015), [2] the extent of access learners have with the course academic, and [3] course resources and peer interaction (Hew, 2014; Marks, Sibley, \& Arbaugh, 2005). Hone and El Said (2016) also found academic interaction with learners in online provision to be a significant predictor of retention. Again, this demonstrates the range of considerations for HEIs during the COVID-19 pandemic and beyond. Indeed, previous 
research (Petronzi \& Hadi, 2016) that explored feedback from online learners showed the importance of academic involvement and peer interaction via discussion boards that offered learners a platform to share experiences and to gain support. This is deliverable provision but can also be expanded upon using live collaborative digital solutions e.g. Microsoft TEAMS and Collaborate Ultra, to further increase engagement and simulate a class-based experience that students have become accustomed to. Witney and Smallbone (2011) question if technologyenhanced learning is sufficient if students are not using the technology in a collaborative way. Collaborative learning in a blended approach can, if carefully scaffolded and structured, support critical thinking and problem solving (Francis, 2010; Kuo et al., 2012). Indeed, the findings of Ustan \& Tracey's (2019) study suggested that staff may experience limited time to engage in active feedback within digital learning due to attending to both online and campus delivery. Prior awareness of this potential stumbling block and careful design (Hadi \& Rawson, 2016) can mitigate this by providing meaningful learning opportunities for student-to-student collaboration in faceto-face and virtual settings, as well as tutor-to-student personalised feedback. We incorporate this within our proposed OaC model (Table 1; Figures $1 \&$ 2).

Information diverges from the concept of knowledge (Ashcroft \& Foreman-Peck, 1994) whereby one can simply transmit information, but this may not necessarily support the development of knowledge. Campus workshops are an environment where effective formative assessment can promote active engagement, personalised learning and deeper-processing when compared to traditional, passive and transmission-based lectures (Ashcroft \& Foreman-Peck, 1994; Gibbs, 1992). Synchronous online teaching may be employed to replicate traditional transmission of knowledge in a similar manner to a traditional lecture; however, tutors must create collaborative opportunities to consolidate, challenge, and encourage application of information so that this transfers to knowledge. This will support both the expansion of knowledge through socially constructed processes (Dewey, 2013; Aubrey \& Riley, 2019), but equally provide opportunity for tutors to formatively assess and adapt the teaching content and pedagogical approaches accordingly (Ashcroft \& Foreman-Peck, 1994; Gibbs, 1992). This aligns with the concept of constructivism, which involves learners building on prior knowledge or experiences to make sense of new information (Bates, 2016, Kay \& Kibble, 2015). This often involves a combination of tutor input, problem or activity work and tutor summary (Ashcroft \& Foreman-Peck,1994). In accordance with our proposed blended learning model, face-to-face workshops allow tutors to set group tasks and challenges, assess the learning and respond accordingly, and to share individual progress and successes against the learning objectives (Caine \& Caine, 1997; Curzon, 2006; Knowles, 1984; Reece \& Walker, 2007). These build upon online-based content and we also highlight the association between these in that each method is dependent upon the quality of the other to ensure effective learning. This approach also enables autonomy in that a tutor can reflect on the learning and adapt accordingly.

Nicholls (2002) and Kolb and Kolb (2005) state that learning is an interactive process. Group learning adopts a social constructivist approach, in which tutors become facilitators (Aubrey \& Riley, 2019; Dewey, 2013). Knowles (1984) previously acknowledged that tutors must consider the physical space and the psychological atmosphere to facilitate successful adult group work, although this can be difficult to assess in a digital environment (Ustun \& Tracey, 2020). Group work challenges learners by encountering divergent opinions, learning through peer modelling, risk-taking and engaging in collaborative problem-solving (Alexander, 2017; Aubrey \& Riley, 2019; Dennick, 2012; Kolb \& Kolb, 2005). It should be noted, however, that collaborative/group work is not limited to face-to-face sessions (Petronzi \& Hadi, 2016). While we place emphasis on the campus setting for peer-to-peer engagement, the use of collaborative digital software, including group discussion boards, can replicate group work through producing a dialogic environment (Gibson, 2012). This pedagogy is dependent on students and tutors taking account of what all say and raising new questions from the dialogue (Bakhtin, 1986). Therefore, dialogic learning is a student-centred approach that may require incidental and planned scaffolding from the tutor 
(Simpson, 2016). Here, we explicitly refer to Ustan \& Tracey's (2019) concerns regarding staff availability, as a dialogic approach creates a learning community, as well as having access to an expert tutor.

\section{Online and Campus $(\mathrm{OaC})$ Model}

Following a review of pertinent pedagogical literature up to this stage, we present the Online and Campus $(\mathrm{OaC})$ pedagogical model and depict this in Table 1 and Figures 1 and 2. This model is intended for teaching and learning in HEIs utilising blended learning as a standardised approach. Although this paper is written post COVID-19, the model presented can be utilised as a progressive approach to learning and teaching, rather than a temporary solution. Table 1 and Figures 1 and 2 represent the $\mathrm{OaC}$ model and suggested examples, including a summary of student experience and tutor roles and responsibilities.

Table 1.

A depiction of the Online and Campus $(\mathrm{OaC})$ model with a suggested route and summary of tutor roles and student experience for each stage of the learning process.

\section{Suggested Opportunities and Roles \\ Example}

\begin{tabular}{|c|c|c|}
\hline \multirow{8}{*}{$\begin{array}{l}{[1]} \\
\text { Introduce } \\
\text { Knowledge }\end{array}$} & \multirow{8}{*}{ Asynchronous: } & Student Opportunities/Role: \\
\hline & & $\begin{array}{l}\text { [1] Flexible and accessible engagement with knowledge and theory. } \\
\text { [2] Ability to work at own pace and access different representations of } \\
\text { the same content. }\end{array}$ \\
\hline & & [3] Develop academic and graduate employability skills. \\
\hline & & Tutor Opportunities/Role \\
\hline & & [1] Representation of content to make accessible. \\
\hline & & [2] Embedding of teaching tasks. \\
\hline & & [3] Formative opportunities through tasks. \\
\hline & & [4] Opportunity to provide individualised feedback. \\
\hline \multirow{9}{*}{$\begin{array}{l}\text { [2] Embed/ } \\
\text { Conceptualise }\end{array}$} & \multirow{9}{*}{ Synchronous: } & Student Experience: \\
\hline & & [1] Synchronise knowledge transmission \\
\hline & & [2] Direct tutor contact \\
\hline & & $\begin{array}{l}\text { [3] Less social pressure than campus/more anonymity if supported } \\
\text { correctly can equal higher engagement and more confidence to } \\
\text { responds. }\end{array}$ \\
\hline & & Tutor Opportunities/Role \\
\hline & & [1] Delivery of essential content materials, theory and key messages. \\
\hline & & [2] Active question and answer opportunity. \\
\hline & & [3] Some limited formative assessment through engagement. \\
\hline & & [4] Cohort/group digital collaboration tasks. \\
\hline \multirow{10}{*}{$\begin{array}{l}\text { [3] } \\
\text { Apply/ } \\
\text { Challenge }\end{array}$} & \multirow{10}{*}{ Campus: } & Student Experience: \\
\hline & & [1] Problem-based learning \\
\hline & & [2] Embedding of knowledge with peer and tutor support \\
\hline & & [3] Self-reflection/self-assessment opportunity. \\
\hline & & [4] Dialogic learning and deepening of understanding. \\
\hline & & [5] Social opportunities and team building. \\
\hline & & Tutor Opportunities/Role \\
\hline & & [1] Formative assessment of taught knowledge, adapting task to group \\
\hline & & needs appropriately. \\
\hline & & [2] Practical opportunities and teaching (where required). \\
\hline
\end{tabular}




\section{Psychosocial Environment in a Blended Approach}

We begin this section with a caveat; that psychosocial environment literature is expansive and beyond the scope of this review. However, it would be remiss of us to fail to consider this with regards to planning collaborative opportunities.

Research shows that dialogic learning with sufficient scaffolding can encourage students of all backgrounds and capabilities to engage in learning (Hammond \& Gibbons, 2005; Simpson, 2016). This is particularly important given recent political movements, equality and diversity e.g. social mobility. An environment of mutual respect without fear of failure must be developed (Bates, 2016; Nicholls, 2002). For this to be successful digitally, tutors must define their role - and the role of each member of the group- to students before implementing collaborative tasks to support independent thinking (Bates, 2016; Shayer \& Adey, 2002). For example, if using a discussion board task, students should be made aware of expectations and a code of conduct for interacting with others. This is particularly pertinent given that a cohort of students are not entirely online based; they will - at various stages throughout their programme - meet face-to-face campus and be expected to work collaboratively. The psychosocial environment can also affect connection and belongingness and result in poor engagement with collaborative tasks, as these can affect the psychological motivation of a student (Ghaedi \& Jam, 2014). Dallimore, Hertenstein and Platt (2004) state that student learning can be facilitated through trusting, supportive and interactive climates. This relies on both tutor and student mutually constructing an environment of respect, where students are affirmed by their experiences and ideas being integrated into teaching and discussion (Dallimore et.al., 2004). This, too, promotes a sense of community through student centred learning (Boud, Ajjawi, Dawson \& Tai, 2018; Damşa \& De Lange, 2019; Francis, 2010).

A positive psychosocial environment enriches student-student interaction, which can reinforce core knowledge and support application of theory to practice (Biggs \& Tang, 2011). However, the tutor must facilitate this group work by taking consideration to size, dynamics and student preparation, and generally planning for this as part of the blended approach course design (Biggs \& Tang, 2011; McVicar, Andrew \& Kemble, 2015; Shantakumari \& Sajith, 2015). Yamane (2006, cited in Biggs \& Tang, 2011) suggests random grouping can alleviate the pressure of social grouping situations and support new relationships. However, students can feel discomfort in being separated from their usual social circle (Gloria, Galanes, Heather \& Carmack, 2013). To address this, students must be supported in co-constructing the design of collaborative tasks through open feedback opportunities (Arthur, 2020).

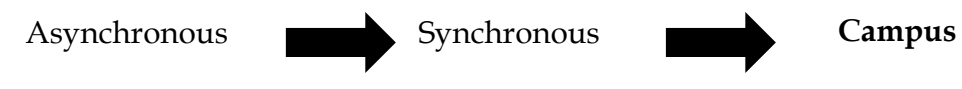

Figure 1. Route 1 example

Synchronous

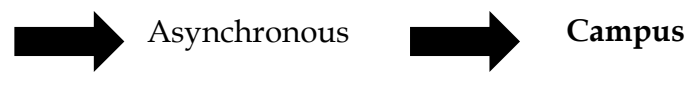

Figure 2. Route 2 example

Figure 1 represents the suggested applied route of the OaC model, although Figure 2 is equally valid.

Based on all the literature reviewed, and the proposed OaC model, we include an example (Table 2) half-semester timetable that shows application of the $\mathrm{OaC}$ model with reference to Figure 2. Colour coding refers to sessions e.g. blue is session 1, orange is session 2 . The white blocks represent formative opportunities and module organisation. 
Table 2.

An example half-semester module plan that incorporates the $\mathrm{OaC}$ model approach to asynchronous, synchronous and campus teaching/learning

\begin{tabular}{|c|c|c|c|}
\hline & Campus & Synchronous learning & Asynchronous learning \\
\hline Week 1 & $\begin{array}{l}\text { Introducing the module campus. } \\
\text { Explaining the expectations for } \\
\text { engagement within a blended } \\
\text { approach and the rationale } \\
\text { behind the delivery method. } \\
\text { Opportunity for social } \\
\text { icebreakers and group } \\
\text { introduction/contact sharing. }\end{array}$ & $\begin{array}{l}\text { Synchronous online } \\
\text { delivery through online } \\
\text { classroom e.g. Collaborate } \\
\text { Ultra for session } 1 \text { content. } \\
\text { Taught content and theory } \\
\text { around session } 1 .\end{array}$ & $\begin{array}{l}\text { Reading task/ discussion } \\
\text { board/ sharing Padlet/Journals } \\
\text { for session } 1 \text { content. Embed } \\
\text { learning through wider } \\
\text { perspective tasks and/or } \\
\text { collaboration. }\end{array}$ \\
\hline Week 2 & $\begin{array}{l}\text { Embed and apply session } 1 \\
\text { learning through dialogic/ } \\
\text { Problem Based Learning (PBL)/ } \\
\text { collaborative session. } \\
\text { Opportunity for formative } \\
\text { assessment and Q\&A. }\end{array}$ & $\begin{array}{l}\text { Synchronous online } \\
\text { delivery through online } \\
\text { classroom e.g. Collaborate } \\
\text { Ultra for session } 2 \text { content. } \\
\text { Taught content and theory } \\
\text { around session } 2 \text {. } \\
\text { As students become more } \\
\text { familiar with content, } \\
\text { introduce some element of } \\
\text { collaboration within this } \\
\text { session e.g. discussion } \\
\text { groups. }\end{array}$ & $\begin{array}{l}\text { Session } 2 \text { student group work. } \\
\text { Students can work } \\
\text { asynchronously and remotely to } \\
\text { produce a shared document e.g. } \\
\text { a shared PowerPoint/ poster. } \\
\text { This requires independent } \\
\text { research and building on the } \\
\text { ideas of others. }\end{array}$ \\
\hline Week 3 & $\begin{array}{l}\text { Embed and apply session } 2 \\
\text { learning through group task. } \\
\text { Students are presented with the } \\
\text { work from another group and } \\
\text { apply this in a discipline specific } \\
\text { problem-based learning task e.g. } \\
\text { applying theory to a case study } \\
\text { to suggest potential therapy } \\
\text { strategies. } \\
\text { Opportunity for formative } \\
\text { assessment and Q\&A. }\end{array}$ & $\begin{array}{l}\text { Synchronous online } \\
\text { delivery through online } \\
\text { classroom e.g. Collaborate } \\
\text { Ultra for session } 3 \text { content. } \\
\text { Taught content and theory } \\
\text { around session } 3 \text {. }\end{array}$ & $\begin{array}{l}\text { Asynchronous quiz and } \\
\text { reflective task/journaling. Use } \\
\text { of multimedia tools e.g. videos } \\
\text { to support practice of the } \\
\text { concept/theory. }\end{array}$ \\
\hline Week 4 & $\begin{array}{l}\text { Build on session } 3 \text { learning, } \\
\text { dialogic/PBL/ collaborative } \\
\text { learning session. } \\
\text { Opportunity for formative } \\
\text { assessment and Q\&A. }\end{array}$ & $\begin{array}{l}\text { Synchronous online } \\
\text { delivery through online } \\
\text { classroom of session } 4 \\
\text { theory/content }\end{array}$ & $\begin{array}{l}\text { Reading task/ discussion } \\
\text { board/ sharing } \\
\text { Padlet/Journals/multimedia for } \\
\text { session } 4\end{array}$ \\
\hline Week 5 & $\begin{array}{l}\text { Session } 4 \\
\text { Dialogic/PBL/collaborative } \\
\text { learning session } \\
\text { Opportunity for formative } \\
\text { assessment and Q\&A. }\end{array}$ & $\begin{array}{l}\text { Synchronous online } \\
\text { delivery through online } \\
\text { classroom of session } 5 \\
\text { theory/content }\end{array}$ & $\begin{array}{l}\text { Reading task/ discussion } \\
\text { board/ sharing } \\
\text { Padlet/journals/multimedia for } \\
\text { session } 5 \text {. }\end{array}$ \\
\hline Week 6 & $\begin{array}{l}\text { Session } 5 \\
\text { Dialogic/PBL/collaborative } \\
\text { learning session } \\
\text { Opportunity for formative } \\
\text { assessment and Q\&A. }\end{array}$ & $\begin{array}{l}\text { Synchronous assessment } \\
\text { support session. Guided } \\
\text { reflection on the learning } \\
\text { throughout the first } 6 \\
\text { weeks. Opportunity to ask } \\
\text { questions to tutor and to } \\
\text { peers. }\end{array}$ & $\begin{array}{l}\text { Formative assessment task e.g. } \\
\text { draft, discussion board, mini } \\
\text { presentation video. } \\
\text { Begin assessment support } \\
\text { discussion board thread. }\end{array}$ \\
\hline
\end{tabular}




\section{Conclusion}

The nature of online learning naturally demands that learners manage their own learning and are intrinsically motivated. As students who enrolled for a primarily campus experience move towards blended approaches, providers must consider how to motivate and support students in engaging with digital and asynchronous materials. This therefore requires structure and guidance to support academics in designing a blended module, that aligns the course objectives with the content to ensure a more meaningful and clearly defined learning experience. Research surrounding blended approaches in education have supported a range of advantages in comparison to traditional - and potentially more passive - didactic learning approaches, for example, deeper learning, increased flexibility, more active engagement and the development of self-managed learning. Work in this area also suggests that the campus experience can benefit from more dedicated active sessions, as core knowledge is taught through online opportunities. In this way, the campus experience may be reappraised as an opportunity to apply/challenge information. Moreover, the socialisation of digital learning - with regards to both motivation and acquiring knowledge - has been explored through the literature in this paper. The model proposed through exploring relevant literature has identified the need for a clear association and connection between campus, digital synchronous and digital asynchronous approaches. This paper approaches blended learning from a generic perspective and as such, individual disciplines must consider the nature of the subject when determining the appropriate use of blended elements. The OaC model - at the time of proposal (before the 2020/21 academic year) - formed the basis of an undergraduate module delivery in a UK HEI. Although, informally, student feedback has indicated a positive experience following the implementation of this model, empirical data is needed - both qualitative and quantitative - to further validate this blended learning model.

Acknowledgements. The author(s) declare no potential competing interests with respect to the research, authorship, and/or publication of this article.

\section{References}

Anthony, B., Kamaludin, A., Romli, A., Raffei, A. F. M., Phon, D. N. A. E., Abdullah, A., \& Ming, G. L. (2020). Blended learning adoption and implementation in higher education: A theoretical and systematic review. Technology, Knowledge and Learning, 1-48. doi: 10.1007/s10758-020-09477-z.

Alexander, R. J. (2017) Towards dialogic teaching: rethinking classroom talk (5th Ed), Dialogos: York.

Arthur, L. (2020). Evaluating student satisfaction - restricting lecturer professionalism: outcomes of using the UK national student survey questionnaire for internal student evaluation of teaching. Assessment $\mathcal{E}$ Evaluation in Higher Education, 45, 331-344. doi: 10.1080/02602938.2019.1640863.

Ashcroft, K. \& Foreman-Peck, L. (1994). Managing teaching and learning in further and higher education. London: Routledge.

Aubrey, K., \& Riley, A. (2018). Understanding and using educational theories, (2nd Ed). London: Sage.

Alexander, R. J. (2017). Towards dialogic teaching: rethinking classroom talk (5th Ed). York: Dialogos.

Azhar, M., Mustapa, S., Ibrahim, M., \& Yusoff, A. (2015). Engaging vocational college students through blended learning: Improving class attendance and participation. Procedia-Social and Behavioral Sciences, 204, 127-135. doi: 10.1016/j.sbspro.2015.08.125.

Baepler, P., Walker, J. D., \& Driessen, M. (2014). It's not about seat time: Blending, flipping, and efficiency in active learning classrooms. Computers \& Education, 78, 227-236. doi: 10.1016/j.compedu.2014.06.006.

Bakhtin, M. M. (1986). Speech genres and other late essays. Translated by Vern W. McFee. Austin, Texas: University of Texas Press.

Bates, B. (2016). Learning theories simplified -and how to apply them to teaching. London: Sage

Biggs, J., \& Tang, C. (2011) Teaching for Quality Learning at University. (4 $4^{\text {th }}$ Ed). Maidenhead: OUP.

Boud, D., Ajjawi, R., Dawson, P., \& Tai, J. (2018). Developing evaluative judgement in higher education: Assessment for knowing and producing quality work. London: Routledge.

Caine, R. N., \& Caine, G. (1998). Unleashing the power of perceptual change: The potential of brain-based teaching. National Association of Secondary School Principals. NASSP Bulletin, 82, 121. 
Chris, B., \& Blackstock, D. (2017). Building on world-class quality (pp. 1-15, Rep.). Quality Assurance Agency.

Chu, A., \& Westerheijden, D. F. (2018). Between quality and control: what can we learn from higher education quality assurance policy in the Netherlands. Quality in higher education, 24, 260-270. doi: 10.1080/13538322.2018.1559513.

Curzon, L. B. (2006). Teaching in further education $\left(6^{\text {th }}\right.$ ed). London: Continuum.

Dallimore, E. J., Hertenstein, J. H., \& Platt, M. B. (2004). Classroom participation and discussion effectiveness: Student-generated strategies. Communication Education, 53, 103-115. doi: $10.1080=0363452032000135805$.

Damşa, C., \& De Lange, T. (2019). Student-centred learning environments in higher education. Uniped, 42, 926.

Day, C., Gu, Q., \& Sammons, P. (2016). The impact of leadership on student outcomes: How successful school leaders use transformational and instructional strategies to make a difference. Educational Administration Quarterly, 52, 221-258.

Dennick, R. (2012). Twelve tips for incorporating educational theory into teaching practices. Medical Teacher, 34, 618-624. doi: 10.3109/0142159X.2012.668244.

Ertmer, P. A. (2005). Teacher pedagogical beliefs: The final frontier in our quest for technology integration? Educational Technology Research and Development, 53, 25-39.

Francis, R. (2010). The decententering of the university. The future of (self)education in virtually figured worlds. London: Routledge.

Glance, D. G. (2013, February 11). The business of MOOCs: How to profit from giving away something for nothing. The Conversation. Retrieved from

https://theconversation.com/the-business-of-moocs-how-to-profit-from-giving-away-something-fornothing-12141.

Graham, C. R., Allen, S., \& Ure, D. (2005). Benefits and challenges of blended learning environments. In M. Khosrow-Pour (Ed.), Encyclopedia of Information Science and Technology (pp. 253-259). Hershey: Idea Group.

Greene, J. A., Oswald, C. A., \& Pomerantz, J. (2015). Predictors of retention and achievement in a Massive Open Online Course. American Educational Research Journal, 52, 925-955.

Gibbs, G. (1992). Improving the quality of student learning. Bristol: Technical and Educational Services Ltd.

Gibson, S. (2012). Narrative accounts of university education: Socio-cultural perspectives of students with disabilities. Disability and Society, 27, 353-369.

Hammond, J., \& Gibbons, P. (2005). Putting scaffolding to work: the contribution of scaffolding in articulating ESL education. Prospect, 20, 6-30.

Hadi, S. M., \& Rawson, R. (2016). Driving learner engagement and completion within MOOCs: a case for structured learning support. Paper presented at the European MOOCs Stakeholder Summit.

Hayes, S. (2015). MOOCs and Quality: A review of the recent literature. Retrieved October 5, 2020, from http://www.qaa.ac.uk/en/Publications/Documents/MOOCs-and-Quality-Literature-Review-15.pdf

Hew, K. F. (2016). Promoting engagement in online courses: What strategies can we learn from three highly rated MOOCS. British Journal of Educational Technology, 47, 320-341. doi: 10.1111/bjet.12235.

Hone, K. S., \& El Said, G, R. (2016). Exploring the Factors Affecting MOOC Retention: a Survey Study. Computers and Education, 98, 157-168.

Jokinen, P., \& Mikkonen, I. (2013). Teachers' experiences of teaching in a blended learning environment. Nurse Education in Practice, 13, 524-528.

Koehler, M., \& Mishra, P. (2009). What is technological pedagogical content knowledge (TPACK)? Contemporary Issues in Technology and Teacher Education, 9, 60-70.

Kolb, A., \& Kolb, D. A. (2005). Learning styles and learning spaces: Enhancing experiential learning in higher education. Academy of Management Learning and Education, 4, 193-212.

Knowles, M. (1984). Andragogy in action: applying modern principles of adult learning. Michigan: Wiley.

Marks, R. B., Sibley, S. D., \& Arbaugh, J. B. (2005). A structural equation model of predictors for effective online learning. Journal of Management Education, 29, 531-563.

McCutcheon, K., Lohan, M., Traynor, M., \& Martin, D. (2015). A systematic review evaluating the impact of online or blended learning vs. face-to-face learning of clinical skills in undergraduate nurse education. Journal of Advanced Nursing, 71, 255-270. doi: 10.1111/jan.12509.

McVicar, A., Andrew, S., \& Kemble, R. (2015). The 'bioscience problem' for nursing students: An integrative review of published evaluations of Year 1 bioscience, and proposed directions for curriculum development. Nurse Education Today, 35, 500-509. doi: 10.1016/j.nedt.2014.11.003. 
Means, B., Toyama, Y., Murphy, R., \& Baki, M. (2013). The effectiveness of online and blended learning: A meta-analysis of the empirical literature. Teachers College Record, 115, 1-47.

Nicholls. G. (2002). Developing teaching and learning in higher education. London: Routledge.

Petronzi, D., \& Hadi, M. (2016). Exploring the factors associated with MOOC engagement, retention and the wider benefits for learners. European Journal of Open, Distance and E-Learning, 19. doi: 10.1515/eurodl2016-0011

Rasheed, R. A., Kamsin, A., \& Abdullah, N. A. (2020, January). Students and teachers' challenges of using technology in blended learning environments. In Proceedings of the 2020 the 3rd International Conference on Computers in Management and Business (pp. 195-200).

Reece, L., \& Walker, S. (2007). Teaching, training and learning (6 ${ }^{\text {th }}$ Ed). Sunderland: Business Education Publishers.

Shantakumari, N., \& Sajith, P. (2015). Blended learning: The student viewpoint. Annals of Medical and Health Sciences Research, 5, 323-328. doi: 10.4103/2141-9248.165248.

Shayer, M. (2003). Not just Piaget; not just Vygotsky, and certainly not Vygotsky as alternative to Piaget. Learning and instruction, 13, 465-485.

Simpson, A. (2016). Designing pedagogic strategies for dialogic learning in higher education. Technology, Pedagogy and Education, 25, 135-151. doi: 10.1080/1475939X.2015.1038580.

Skylar, A. A. (2009). A comparison of asynchronous online text-based lectures and synchronous interactive web conferencing lectures. Issues in Teacher education, 18, 69-84.

Stein, J., \& Graham, C. R. (2020) (2nd Ed). Essentials for blended learning: A standards-based guide. New York: Routledge.

Tight, M., Mok, K. H., Huisman, J., \& Morphew, C. (Eds.). (2009). The Routledge international handbook of higher education. Routledge.

Tubagus, M., Muslim, S., \& Suriani, S. (2020). Development of learning management system-based blended learning model using claroline in higher education. International Journal of Interactive Mobile Technologies, 14, 186-194. doi: 10.3991/ijim.v14i06.13399.

Ustun, A. B., Tracey, M. W. (2020). An effective way of designing blended learning: A three phase designbased research approach. Education and Information Technologies, 1529-1552. doi: 1007/s10639-019-09999-9.

Vallée, A., Blacher, J., Cariou, A., \& Sorbets, E. (2020). Blended learning compared to traditional learning in medical education: systematic review and meta-analysis. Journal of Medical Internet Research, 22, doi: $10.2196 / 16504$.

Voss, B. D. (2013). Massive open online courses (MOOCs): A primer for university and college board members. AGB Association of Governing Boards of Universities and Colleges.

Witney, D., \& Smallbone, T. (2011). Wiki work: Can using wikis enhance student collaboration for group assignment tasks? Innovations in Education and Teaching International, 48, 101-110. doi: 10.12691/education4-6-4.

Ying, A. N. L., \& Yang, I. (2017). Academics and learners' perceptions on blended learning as a strategic initiative to improve student learning experience. In MATEC Web of Conferences (Vol. 87, p. 04005). EDP Sciences. 